\title{
Unit Cost Prediction Model Development for the Domestic Reinforced Bar using System Dynamics
}

\author{
Yongho $\mathrm{Ko}^{1}$, Seungho $\mathrm{Choi}^{2}$, Youngsuk Kim ${ }^{3}$, and Seungwoo Han ${ }^{4}$
}

\begin{abstract}
Construction industry has become a larger and highly competitive industry. A successful construction project cannot be achieved only by efficient and fast construction techniques but also reasonable material cost and adequate transferring time of materials to installation. The steel industry in East Asia has become the mainstream in overall steel industries in over the world during the middle of the 21st century. China, Japan and Korea has been the main exportation countries. However, even though the international economic failure, China has increased the exportation amount and became an only exporting country which must be considered a serious problem regarding competitiveness in the international steel exportation industry. Thus, this study analyses the factors affecting the supply and demand amount of reinforced bars in the domestic field and moreover suggesting a unit cost prediction model using the System Dynamics simulation methodology, one of powerful prediction tools using cause-effect relationships. It is expected that this study contributes to the domestic steel industry growth in competitiveness in the international industry. In addition, the methodology used in this paper presents the frameworks for appropriate tools for market trend analysis and prediction of other markets.
\end{abstract}

Keywords: reinforced bars, steel industry, system dynamics, competitiveness

\section{INTRODUCTION}

The development of construction industry has been one of key factors to the domestic economic growth and expansion. The growth of an industry is highly depended on an efficient resources providing system. The amount of cement required in the construction industry has been increasing due to the increase in high-rise construction projects. That increase in size has also increased the need for steel materials. This has been an issue not only in Korea but also in Japan and China that the Asian export competition has become more important [1]. According to the research of Korea Iron and Steel Association in 2005, the domestic exportation percentage of reinforced bars and H-beams has shown a low percentage of $2.6 \%$ and $8.8 \%$. In 2003, Japan has also shown a low percentage of $2.4 \%$ and $3.3 \%$. China has shown $6 \%$ and $3.5 \%$. The overall reinforced bars and H-beam exportation internationally in 1995 was 236.5 million ton, in 2000 it was 298.7 million ton and in 2004 it was 363.2 million ton which as can be seen shown an increase. The exportation in Asia has also been increasing in the same period. In 1995 it was 83.6 million ton, in 2000 it was 85.3 million ton and in 2004 it was 116.5 million ton [9]. China has shown a $150 \%$ increase and in 2006 it has recorded a $0 \%$ of importation. This indicates that China has become a $100 \%$ steel material exportation country which can be analyzed as a large decrease in the domestic steel industry regarding exportation.
The purpose of this study is to develop a unit cost prediction model by using the System Dynamics methodology to suggest define the factors affecting unit cost of steel materials focusing on reinforcing bars. The model is expected to contribute to other studies domestically and abroad by using the model and applying each desired data available.

\section{LITERATURE REVIEW}

\section{A. The status of the international steel industry}

Since 1970, the domestic steel industry has been a key factor to the economic development. The steel industry of East Asia has been increasing since the late 21th century. In 2000, the Asian steel industry marked $34 \%$ increase in size of total 288 MT. Moreover, during eight years it has marked additional $50 \%$ increase and became the main steel industry in the world. In 2008, the total amount in China was 453 MT, 83 MT in Japan, 61 MT in Korea and 55 MT in other Asian countries besides the countries mentioned above. As mentioned, in the middle of the 21 st century the steel industry in East Asia has become the main exportation industry [3]. According to the study of the world steel association, it has been suggested that the total steel produced during the year of 2011 is 1.49 billion ton. The association also suggests that the production amount in Asia is 954 million ton which is $64 \%$ of the overall amount

\footnotetext{
${ }^{1}$ Master Candidate, Inha University, 100 Inha-ro, Nam-gu, Incheon, South Korea, yonghofan@hotmail.com

2 Master Candidate, Inha University, 100 Inha-ro, Nam-gu, Incheon, South Korea, hanese12@nate.com

${ }^{3}$ Professor, Inha University, 100 Inha-ro, Nam-gu, Incheon, South Korea, youngsuk@inha.ac.kr

${ }^{4}$ Associate Professor, Inha University, 100 Inha-ro, Nam-gu, Incheon, South Korea, shan@inha.ac.kr (*Corresponding Author)
} 
of steel produced over the world. However, the amount of steel produced in China is 683 million ton, 107 million ton in Japan and 68 million in South Korea which is only $7 \%$ of the Asian producing amount and $4.5 \%$ of the overall producing amount in the world [10]. The cost of the steel frames has been $\$ 300 \sim \$ 400$ since 1970 to 2000 however it has been increased to $\$ 858$ per ton in 2007 due to the international economic failure. This can be analyzed as the main factor of percentage increase of Chinese steel usage in the world due to the low price and acceptable quality. The international usage of Korean steel resources in 2009 are $5.4 \%$ which is a low amount compared to $12.0 \%$ of China in 2008. Even the international economic failure China has been increasing the amount of exportation and in 2009 became the most powerful steel industry in Asia. That is an important matter to the Korean steel industry which is in danger of losing competitiveness in the international industry. Thus, the purpose of this paper is to suggest a methodology of predicting the amount of steel resources demanded and needed to be supplied in the domestic construction industry by analyzing the relationship between the data.

\section{B. Previous Researches of System Dynamics applied in the Construction Field}

System dynamics has been applied in numerous studies in the construction field. Table 1 shows briefly the previous studies using system dynamics.

TABLE I

PREVIOUS RESEARCHES

\begin{tabular}{|c|c|c|}
\hline Author & Thetis & \\
\hline $\begin{array}{l}\text { Cha, } \\
\text { Woo- } \\
\text { Chul et } \\
\text { al }\end{array}$ & $\begin{array}{l}\text { Assessment } \\
\text { Model of a } \\
\text { Construction } \\
\text { Company's } \\
\text { Management } \\
\text { Performance }\end{array}$ & $\begin{array}{l}\text { Deals with the management system of } \\
\text { sub-contractors and suggests a } \\
\text { decision making assisting model. } \\
\text { However, The suggested model has } \\
\text { limitations on verifying the results } \\
\text { quantitatively }\end{array}$ \\
\hline $\begin{array}{l}\text { Hwang, } \\
\text { Sung-joo } \\
\text { et al }\end{array}$ & \begin{tabular}{|c} 
A Dynamic \\
Approach for \\
Evaluating the \\
Validity of \\
Mortgage \\
Lending \\
Policies in \\
Korean Housing \\
Market
\end{tabular} & $\begin{array}{l}\text { Deals with the application of system } \\
\text { dynamics simulation technique on } \\
\text { apartment housing mortgage and the } \\
\text { effect on the apartment housing } \\
\text { industry. However, it has analyzed the } \\
\text { feasibility by qualitative method and } \\
\text { has limitations in applying changed } \\
\text { situations }\end{array}$ \\
\hline $\begin{array}{l}\text { Kang, } \\
\text { Jin- } \\
\text { Young } \\
\text { and } \\
\text { Park, } \\
\text { Hee- } \\
\text { sung }\end{array}$ & $\begin{array}{c}\text { Development of a } \\
\text { Construction } \\
\text { Performance } \\
\text { Causal Map Using } \\
\text { System Dynamics }\end{array}$ & $\begin{array}{l}\text { Deals with an analysis of construction } \\
\text { performance by using system } \\
\text { dynamics and suggests a basic } \\
\text { methodology of predicting } \\
\text { construction performance. However, } \\
\text { the study has suggested preliminary } \\
\text { stages of the research that has } \\
\text { limitations in quantitative analysis. }\end{array}$ \\
\hline $\begin{array}{l}\text { Kim, } \\
\text { Sung- } \\
\text { tae et } \\
\text { al }\end{array}$ & \begin{tabular}{|} 
Supply-Demand \\
Forecasting \\
Method of \\
Qualified \\
Engineers in \\
Construction Using \\
System Dynamics \\
\end{tabular} & $\begin{array}{l}\text { Deals with a quantitative analysis of } \\
\text { Qualified Engineers supply and } \\
\text { demand issues applying changing } \\
\text { national policies. However, the study } \\
\text { requires data from numerous years for } \\
\text { verification. }\end{array}$ \\
\hline $\begin{array}{l}\text { Kim, } \\
\text { Tae- } \\
\text { sung et }\end{array}$ & \begin{tabular}{|c|} 
System Dynamics \\
Approach to \\
Demand and
\end{tabular} & $\begin{array}{l}\text { Deals with the analysis of various } \\
\text { factors affecting manpower } \\
\text { information by using system dynamics }\end{array}$ \\
\hline
\end{tabular}

\begin{tabular}{l|c|l}
\hline al & $\begin{array}{c}\text { Supply of } \\
\text { Information } \\
\text { Security Manpower }\end{array}$ & $\begin{array}{l}\text { methodology to deduct the most } \\
\text { important factor. However, the } \\
\text { analysis lacks statistical data to form } \\
\text { the basic logic of the model. }\end{array}$ \\
\hline
\end{tabular}

\section{SYSTEM DYNAMICS MODEL IMPLEMENTATION}

\section{A. Data Acquisition}

The data has been collected by literature review. Studies in this field using the system dynamics methodology have used smoothed stock variables which is a typical form of system dynamics stock variable. D. Vlachos (2007) has used the exponential smoothing techniques to get the expected values of specific variables of stock variables [4]. However, in this study, the relationship between the variables in the causal loop has been defined as rates deducted by literature review such as the national statistic and steel associations reports. Table 2 shows the representative values that have been used [12].

TABLE II REPRESENTATIVE VALUES

\begin{tabular}{|c|c|c|}
\hline Factor & Initial Value & Rate \\
\hline Exportation rate & 430 kton & $\begin{array}{l}\text { based on relationship- } \\
\text { [INTEG }(0.2 * \text { Domestic } \\
\text { Percentage+0.8*International } \\
\text { Construction Industry Growth } \\
\text { Rate, } 430)]\end{array}$ \\
\hline Importation rate & 862 kton & $\begin{array}{l}\text { based on relationship- } \\
\text { [INTEG(Importation } \\
\text { Rate+0.8*Chinese Resources } \\
\text { Importation } \\
\text { Rate+0.2*"International Steel } \\
\text { Industry Growth Rate", } 862)]\end{array}$ \\
\hline $\begin{array}{c}\text { Domestic industry } \\
\text { volume }\end{array}$ & $\begin{array}{l}131.45 \\
\text { million ton }\end{array}$ & $\begin{array}{l}\text { based on relationship- } \\
\text { [INTEG(construction industry } \\
\text { growth rate, 131405)] }\end{array}$ \\
\hline $\begin{array}{c}\text { Domestic } \\
\text { production rate }\end{array}$ & $15.91 \%$ & $\begin{array}{l}\text { based on relationship- } \\
{[948 *(\mathrm{RAMP}(0.963 * \text { Domesti }} \\
\text { c Steel Industry Working } \\
\text { Rate, } 0,12))+0.037 * \text { Exportatio } \\
\text { n Rate] }\end{array}$ \\
\hline $\begin{array}{c}\text { Chinese } \\
\text { Construction } \\
\text { Industry Growth } \\
\text { Rate }\end{array}$ & $0.181 \%$ & $0.181 \%$ per year \\
\hline $\begin{array}{c}\text { Domestic Steel } \\
\text { Industry Working } \\
\text { Rate }\end{array}$ & $0.741 \%$ & $\begin{array}{l}0.741 \% \text { per year }+\alpha \\
\text { Where } \alpha \text { is: value changes by } \\
\text { time considering the logic } \\
\text { between factors shown in } \\
\text { Table } 3\end{array}$ \\
\hline $\begin{array}{l}\text { Domestic Steel } \\
\text { Industry Growth } \\
\text { Rate }\end{array}$ & $0.083 \%$ & $0.083 \%$ per year \\
\hline $\begin{array}{c}\text { Construction } \\
\text { Industry Growth } \\
\text { Rate }\end{array}$ & $0.074 \%$ & $\begin{array}{l}0.074 \% \text { per year }+\beta \\
\text { Where } \beta \text { is: value changes by } \\
\text { time considering the logic } \\
\text { between factors shown in } \\
\text { Table } 3\end{array}$ \\
\hline $\begin{array}{c}\text { Economic Growth } \\
\text { Rate }\end{array}$ & 0.071 & - \\
\hline
\end{tabular}




\section{B. Factors affecting supply-demand of domestic reinforced bars}

The data has been collected by literature review. Numerous national organizations and statistic reports has been reviewed and the relationship between the data has been analyzed by simple linear relation. At the preliminary stage the factors affecting the supply and demand has been searched. The factors have been attached to three different types of groups of major, main and minor factors. Table 3 shows the factors of the model.

As shown in Table 2, the factors have been chosen and the relationship between the factors has been analyzed. In this study the relationship between the factors has been defined by two types of relationships of forward and backward. Forward relationship means that the factors have a plus linear relationship and backward means minus. For example, if there is forward relationship between factors $\mathrm{A}$ and $\mathrm{B}$ that means that if $\mathrm{A}$ is increasing than $\mathrm{B}$ is also increasing linear. Therefore the factors have been defined as rates and numerical values mostly to be able to apply the logic in the system dynamics model.

TABLE III

FACTORS AFFECTING SUPPLY-DEMAND

\begin{tabular}{|c|c|c|c|}
\hline Group & Number & Factor & Relation \\
\hline \multirow{2}{*}{ Major } & 1 & Supply & 4,6 \\
\hline & 2 & Demand & 3,5 \\
\hline \multirow{4}{*}{ Main } & 3 & Domestic industry volume & 7 \\
\hline & 4 & Domestic production rate & 5,18 \\
\hline & 5 & Exportation rate & 12,23 \\
\hline & 6 & Importation rate & 24,28 \\
\hline \multirow{23}{*}{ Minor } & 7 & Construction industry growth rate & 8 \\
\hline & 8 & Economic growth rate & - \\
\hline & 9 & R\&D growth rate & 8 \\
\hline & 10 & R\&D on steel growth rate & 9 \\
\hline & 11 & Domestic industry reliability & 10 \\
\hline & 12 & Domestic percentage & 11 \\
\hline & 13 & Industrial growth oversea & - \\
\hline & 14 & $\begin{array}{l}\text { Raw material importation growth } \\
\text { rate }\end{array}$ & 13 \\
\hline & 15 & Raw material price growth rate & - \\
\hline & 16 & Steel scrap price growth rate & - \\
\hline & 17 & Production price growth rate & 15,16 \\
\hline & 18 & $\begin{array}{l}\text { Domestic steel industry working } \\
\text { rate }\end{array}$ & $\begin{array}{l}9,14,17 \\
19,20,21\end{array}$ \\
\hline & 19 & $\begin{array}{l}\text { Domestic steel industry growth } \\
\text { rate }\end{array}$ & - \\
\hline & 20 & Steel resources order growth rate & 7 \\
\hline & 21 & Steel industry R\&D support & 22 \\
\hline & 22 & $\begin{array}{c}\text { Steel industry percentage in the } \\
\text { GDP }\end{array}$ & - \\
\hline & 23 & $\begin{array}{l}\text { International construction } \\
\text { industry growth rate }\end{array}$ & 25 \\
\hline & 24 & $\begin{array}{l}\text { Chinese resources importation } \\
\text { rate }\end{array}$ & 25,26 \\
\hline & 25 & $\begin{array}{c}\text { Chinese construction industry } \\
\text { growth rate }\end{array}$ & - \\
\hline & 26 & Importation limitation policies & 24 \\
\hline & 27 & $\begin{array}{c}\text { M\&A of international steel } \\
\text { industry downstream growth rate }\end{array}$ & - \\
\hline & 28 & $\begin{array}{l}\text { International steel industry } \\
\text { growth rate }\end{array}$ & 27,29 \\
\hline & 29 & WTO safety regulations & - \\
\hline
\end{tabular}

\section{Model Implementation}

System dynamics has been widely applied in the study of industry, environment, society, economics etc. in order to analyze systems and suggest prediction models. The most powerful advantage of the system dynamics modeling is the quantitative analysis of various relationships connected to numerous factors at once. In system dynamics, stock means the storage amount and flow is the valve part that controls the change of stock. Variable is the factor controlling the relationship and the rate of flow. Figure 1 shows an example of a system dynamics model [11].

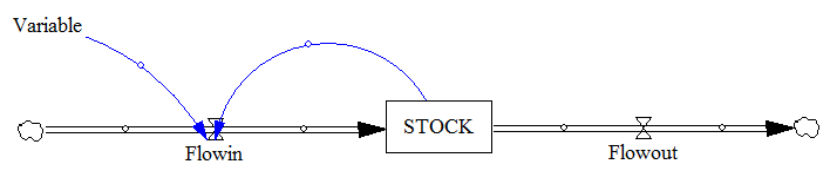

FIGURE I

STOCK AND FLOW STRUCTURE

The stock of this study is the unit cost of reinforced bars. Based on the collected data there is able to predict the change of unit cost by time. The two major factors of supply and demand have been defined as variables in the flow that it is most likely to affect the most on the unit cost. Figure 2 shows the main structure of the unit cost prediction model.

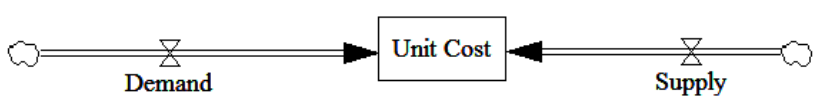

FIGURE II

UNIT COST PREDICTION MODEL MAIN STRUCTURE

In this study, the demand and supply of reinforced bars in the domestic industry have been analyzed as the major factors affecting unit cost of reinforced bars that the major structure of the system has been built as Figure 2. As shown in Table 2, the main factors have been defined as domestic industry volume, domestic production rate, exportation rate and importation rate. Numerous relationship logics have been suggested and Figures 3 shows the relationship logics applied to the domestic industry volume.

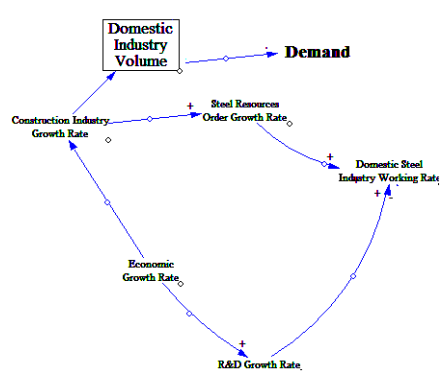

FIGURE III

DOMESTIC INDUSTRY VOLUME RELATIONSHIP 
It can be seen that the domestic industry volume is affected by the construction industry growth rate. The construction industry growth rate variable changes by the function "RAMP( $0.074,0,12)+0.6 *$ Economic Growth Rate". The average growth rate has been deducted from literature review by calculating the average growth rate within the years suggested in the report. The economic growth rate variable has been calculated the same way which as can be seen that has a direct effect on the R\&D growth rate by the domestic policy. This can be used in other countries by applying the suggested rates of R\&D in the country and calculating the average growth rate as done in this model. Figure 4 shows the relationship applied to the domestic production rate.

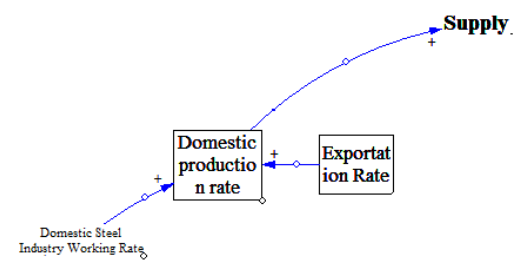

FIGURE IV

DOMESTIC PRODUCTION RATE RELATIONSHIP

The domestic production rate variable is defined as the reinforced bars production rate in South Korea. The variable is affected by the exportation rate variable and the domestic steel industry working rate variable. It has been analyzed that a linear relationship of 0.037 is existing between the exportation rate and the domestic production rate by calculating the dividing the average growth rates of each variable. Figure 5 shows the relationship applied to the exportation rate.

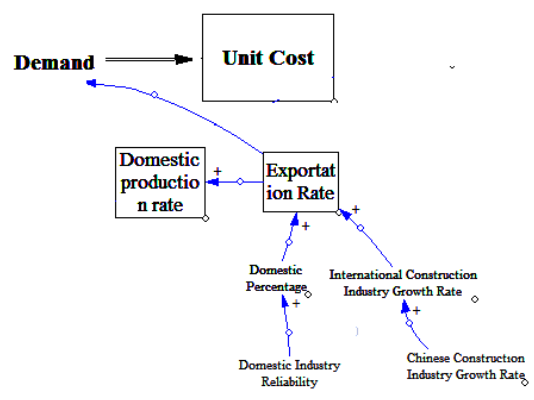

FIGURE V

EXPORTATION RATE RELATIONSHIP

It can be seen that the exportation rate is affected by the domestic percentage and international construction industry growth rate. The domestic percentage variable is defined as the South Korean steel industry percentage rate of the international steel industry. International construction industry growth rate variable has been deducted by calculating the average growth rates by literature review. Figure 6 shows the relationship applied to the importation rate.

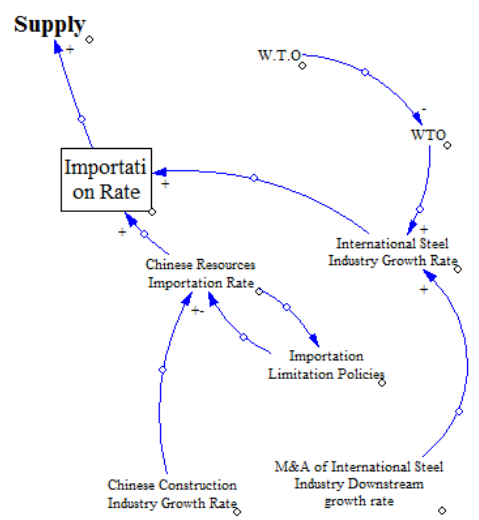

FIGURE VI

IMPORTATION RATE RELATIONSHIP

The relationship of importation rate has been deducted as the above figure. It has been analyzed that the Chinese resources importation rate has a large effect on the importation rate of other countries due to low price and acceptable quality. Therefore, it can be seen that the Chinese resources importation rate has a direct impact on the domestic importation rate. As shown in Figures 3-6, different logics with different variables have been applied. In addition, one minor factor has been considered as key factor affecting the main factors. Domestic Steel Industry Working Rate has been analyzed that it has deep connection to many minor factors. Figure 7 shows the relationship of the factor. The overall model has been built by applying all the logics shown in Figures 3-6. Figure 8 shows the overall model of unit cost prediction model.

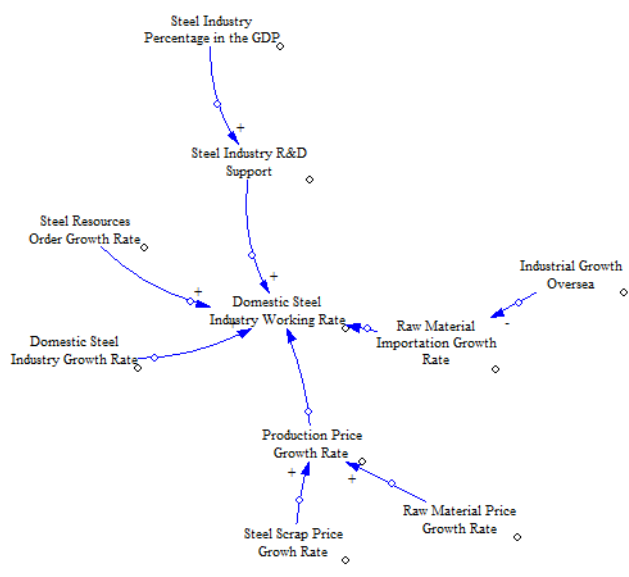

FIGURE VII

DOMESTIC STEEL INDUSTRY WORKING RATE RELATIONSHIP

The model has been built based on analyzed relationships between factors. The relationship between factors has been defined in Vensim program by the use of ramp function mostly. Ramp function has been used mostly due to the properties of the variables. As mentioned above, most of the variables have been defined in rates to be able to apply the changing values quantitatively. Table 4 shows the functions applied to the factors. 
TABLE IV

INPUT FUNCTION IN VENSIM PROGRAM

\begin{tabular}{|c|c|c|}
\hline Factor & Function & Unit \\
\hline Supply & $0.027 *$ Domestic Industry Volume+Exportation Rate & 10 kton \\
\hline Demand & (Domestic production rate+Importation Rate) & 10 kton \\
\hline WTO Safety Regulations & $\operatorname{RAMP}(0.143,0,12)^{*} " \mathrm{WTO} "$ & Year \\
\hline $\begin{array}{l}\text { M\&A of International Steel Industry } \\
\text { Downstream growth rate }\end{array}$ & $\operatorname{RAMP}(0.063,0,12)$ & Year \\
\hline Importation Rate & $\begin{array}{l}\text { INTEG(Importation Rate+0.8*Chinese Resources Importation Rate+0.2*"International Steel } \\
\text { Industry Growth Rate", 862) }\end{array}$ & 10 kton \\
\hline Chinese Resources Importation Rate & $\begin{array}{l}\text { INTEG(IF THEN ELSE(Chinese Resources Importation Rate }>520 \text {, Chinese Resources } \\
\text { Importation Rate+ }(0.7 * \text { Chinese Construction Industry Growth Rate*503.7)- }(0.7 * \text { Chinese } \\
\text { Construction Industry Growth Rate503.7)),503.7) }\end{array}$ & 10 kton \\
\hline Chinese Construction Industry Growth Rate & $\operatorname{RAMP}(0.181,0,12)$ & Year \\
\hline $\begin{array}{l}\text { International Construction Industry Growth } \\
\text { Rate }\end{array}$ & RAMP $(0.043,0,12)+0.3 *$ Chinese Construction Industry Growth Rate & Year \\
\hline Exportation Rate & $\begin{array}{l}\text { INTEG }(0.2 * \text { Domestic Percentage }+0.8 * \text { International Construction Industry Growth Rate, } \\
430)\end{array}$ & 10 kton \\
\hline Domestic Percentage & RAMP $(0.041,0,12)+0.5^{*}$ Domestic Industry Reliability & Year \\
\hline Domestic Industry Reliability & RAMP $(0.028,0,12)+0.4 *$ Steel Industry R\&D Support & Year \\
\hline Steel Industry R\&D Support & RAMP $(0.064,0,12)+0.8 *$ Steel Industry R\&D Support & Year \\
\hline R\&D on Steel Growth Rate & RAMP $(0.058,0,12)+0.4 *$ Economic Growth Rate & Year \\
\hline Economic Growth Rate & 0.071 & Year \\
\hline Construction Industry Growth Rate & RAMP $(0.074,0,12)+0.6^{*}$ Economic Growth Rate & Year \\
\hline Steel Resources Order Growth Rate & $\operatorname{RAMP}(0.025,1,12)+0.15^{*}$ Construction Industry Growth Rate & Year \\
\hline Domestic Steel Industry Working Rate & $\begin{array}{l}\text { RAMP }(0.741,0,12)+0.3 * \text { Domestic Steel Industry Growth Rate }+0.2 * \text { R\&D on Steel Growth } \\
\text { Rate+0.1*Raw Material Price Growth Rate+0.1*Steel Industry R\&D Support }+0.3 * \text { Steel } \\
\text { Resources Order Growth Rate+0.1*R\&D Growth Rate }\end{array}$ & Year \\
\hline Domestic Steel Industry Growth Rate & $\operatorname{RAMP}(0.083,0,12)$ & Year \\
\hline Steel Scrap Price Growh Rate & $\operatorname{RAMP}(0.032,0,12)$ & Year \\
\hline Raw Material Price Growth Rate & (Raw Material Importation Growth Rate+Steel Scrap Price Growh Rate)/2 & Year \\
\hline
\end{tabular}

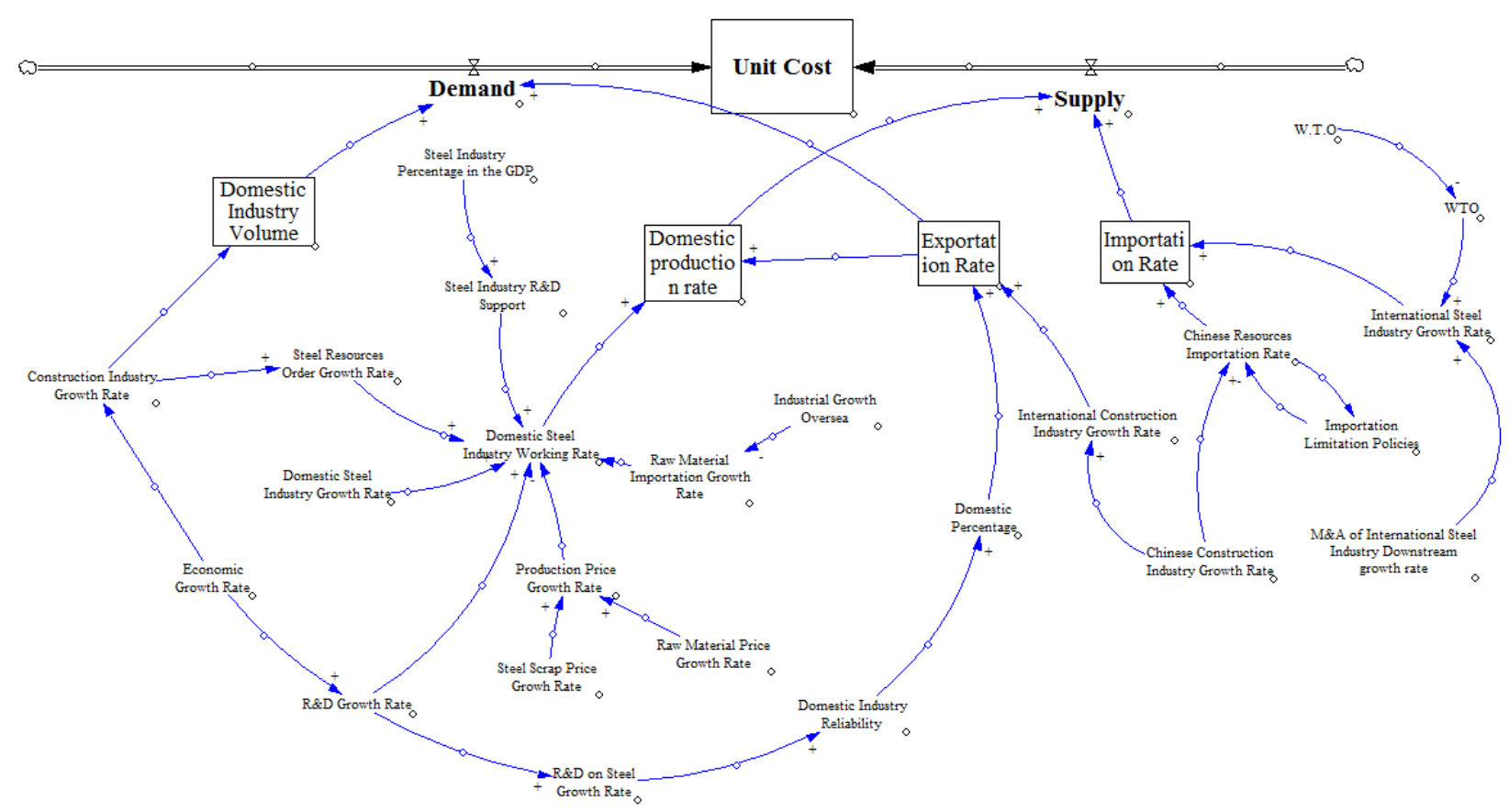

FIGURE VIII

DOMESTIC REINFORCED BARS UNIT COST PREDICTION MODEL 


\section{UNIT COST AND MAIN FACTORS ANALYSIS}

The model suggested in the previous chapter has been analyzed. The analysis has been performed based on the main factors and the domestic steel industry working rate factor using the Vensim program. Figures 9 shows the analysis performed on the domestic steel industry working rate.

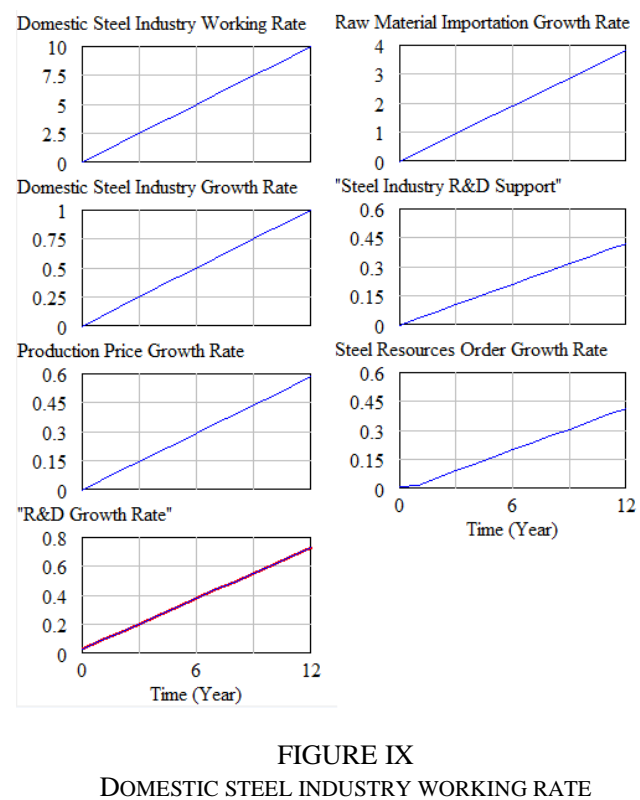

As shown above, the factors affecting domestic steel industry working rate are raw material importation growth rate, domestic steel industry growth rate, steel industry R\&D support, production price growth rate, steel resources order growth rate and $R \& D$ growth rate. The relationship between the factors has been analyzed linearly and the results are as shown in Figure 9. It can be seen that all the relationships are positive rates that each factor has a positive effect on the domestic steel industry working rate factor. Figure 10 shows the domestic industry volume analysis.

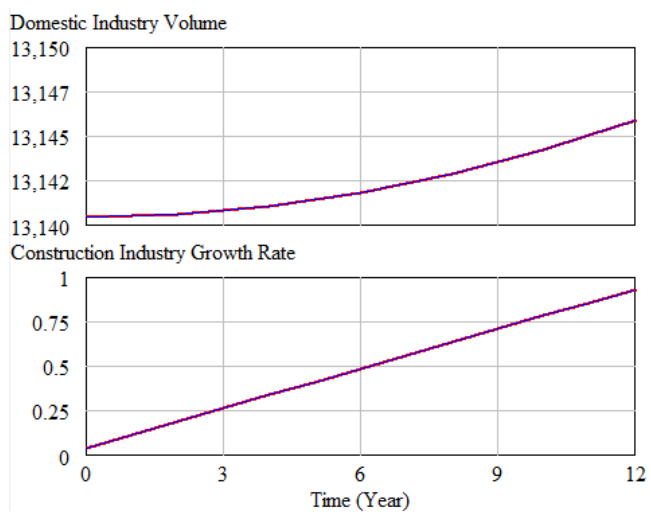

FIGURE X

DOMESTIC INDUSTRY VOLUME

As shown above, the factor affecting domestic industry volume is construction industry growth rate which has been measured by the average growth rate calculated from the collected data. It has been analyzed that the domestic industry volume increases nonlinearly. Figure 11 shows the domestic production rate analysis.

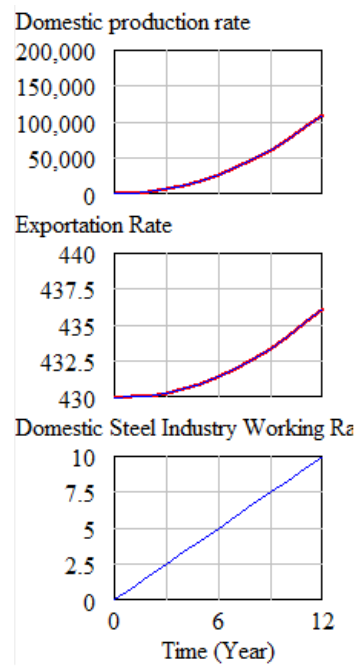

FIGURE XI

DOMESTIC PRODUCTION RATE

As shown above, the factors affecting domestic production rate are exportation rate and domestic steel industry working rate. The domestic steel industry working rate has been simulated by the Vensim program with the logic mentioned in the previous chapter. The exportation rate has shown a nonlinear increase. The domestic production rate has shown a similar increasing rate with exportation rate that it can be analyzed that the exportation rate has a stronger relationship with domestic production rate than the domestic steel industry working rate factor. Figure 12 shows the exportation rate analysis.

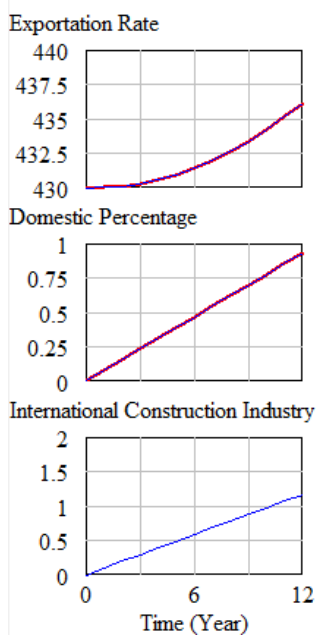

FIGURE XII EXPORTATION RATE

As shown above, the factors affecting exportation rate are domestic percentage and international construction industry growth rate. The domestic percentage has shown a nonlinear increase rate, however it can be seen that it is 
close to a linear increase that in this model it has been assumed as linear relationship. International construction industry growth rate has been calculated by the average growth rate from the collected data.

The factors affecting importation rate are Chinese resources importation rate and international steel industry growth rate. The international steel industry growth rate has shown an increase mostly however has also shown a decrease. The Chinese resources importation rate has shown a nonlinear increase which as written in the previous chapter is most likely to increase more in the future.

The main factors have been analyzed as shown in above figures. Based on that, the major factors supply and demand have been analyzed. Figure 14 and 15 show the analysis of the supply and demand variables.

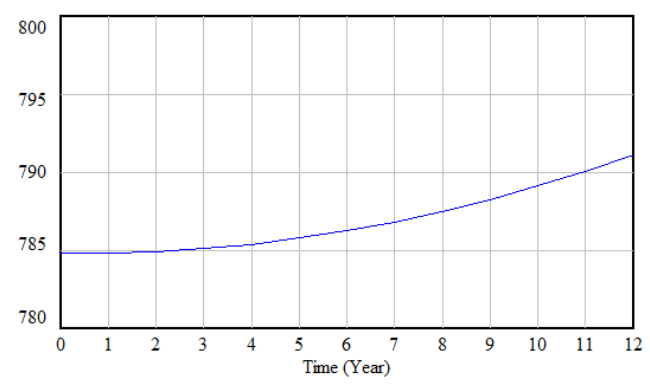

FIGURE XIV

DEMAND FACTOR ANALYSIS

As shown above, the demand factor has shown a nonlinear increase by time. The factors affecting demand are domestic industry volume and exportation rate which both have shown a nonlinear increase.

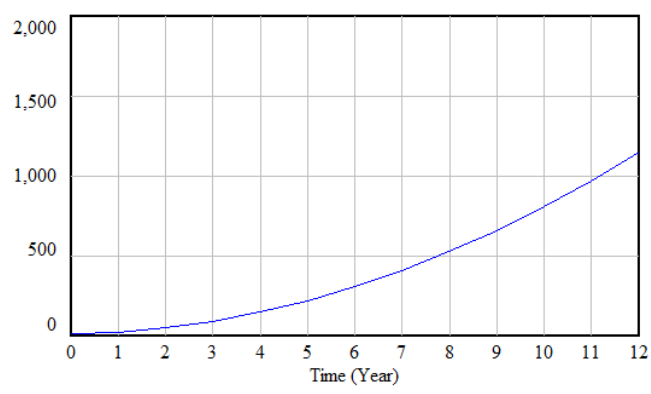

FIGURE XV

SUPPLY FACTOR ANALYSIS

As shown above, the supply factor has shown a nonlinear increase by time. The factors affecting demand are importation rate and domestic production rate. It can be seen that the domestic production rate has a similar curve shape with supply that it can be analyzed that it has stronger effect than the importation rate that has shown an almost linear increase rate. It has been analyzed that the demanded and supplied amount of reinforced bars will have a nonlinear increase during the years. Table 5 shows the amounts by time starting from 2005; the year the data has been collected from.
TABLE V

DEMANDED AND SUPPLIED REINFORCED BARS AMOUNT

\begin{tabular}{|c|c|c|}
\hline Factor & Year & Amount \\
\hline \multirow{13}{*}{ Demand } & 2005 & 7847.94 \\
\hline & 2006 & 7847.96 \\
\hline & 2007 & 7848.93 \\
\hline & 2008 & 7848.93 \\
\hline & 2009 & 7850.85 \\
\hline & 2010 & 7853.73 \\
\hline & 2011 & 7862.35 \\
\hline & 2012 & 7868.08 \\
\hline & 2013 & 7874.77 \\
\hline & 2014 & 7882.41 \\
\hline & 2015 & 7891.01 \\
\hline & 2016 & 7900.55 \\
\hline & 2017 & 7911.05 \\
\hline \multirow{13}{*}{ Supply } & 2005 & 87.79 \\
\hline & 2006 & 20.37 \\
\hline & 2007 & 47.08 \\
\hline & 2008 & 88.92 \\
\hline & 2009 & 145.89 \\
\hline & 2010 & 217.98 \\
\hline & 2011 & 305.20 \\
\hline & 2012 & 407.54 \\
\hline & 2013 & 525.02 \\
\hline & 2014 & 657.63 \\
\hline & 2015 & 805.36 \\
\hline & 2016 & 968.23 \\
\hline & 2017 & 1146.24 \\
\hline
\end{tabular}

Based on the analysis suggested above in this chapter, the unit cost has been analyzed as Figure 16. The analysis duration has been assumed as twelve years. It has been analyzed that during the first five years the unit cost of the reinforced bars does not have any change. However, in the $6^{\text {th }}$ year it increases to 815 thousand won for a year and decreases to 805 thousand won for three years and decreases to 795 thousand won for the last three years.

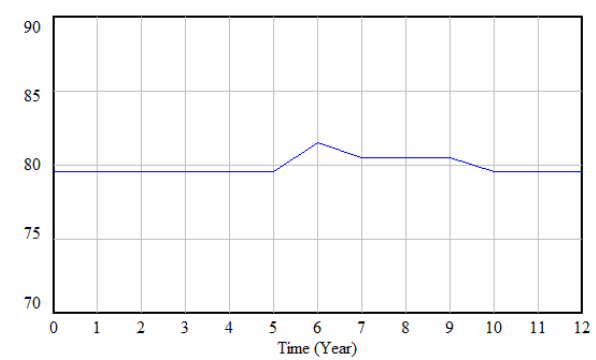

FIGURE XV

UNIT COST ANALYSIS

\section{CONCLUSION}

This paper deals with the study of the status of the international steel industry and the percentage belonging to the domestic steel industry. This paper deducts the factors affecting the domestic steel industry, construction industry, exportation and importation amounts to suggest a supply-demand prediction model by using system dynamics methodology. The main purpose of this paper is to suggest an overall model that is able to apply data quantitatively to investigate the relationship between factors and prepare for the change in unit cost focusing on reinforced bars. The factors have been divided into three 
types of major, main and minor groups so that each group has a relationship with the group above where at the top of the relationship chain where is the unit cost factor. For instance, it presents that the affecting factors to domestic steel industry are growth rates of raw material, domestic steel industry, production prices, R\&D support, steel resources order, and $\mathrm{R} \& \mathrm{D}$. It has been analyzed that the supply and demand of reinforced bars will increase nonlinearly by the years. The results of this study have shown that the unit cost of the reinforced bars increases starting from the $6^{\text {th }}$ year to the $9^{\text {th }}$ year and decreases to the same amount starting from the $10^{\text {th }}$ year.

This study suggests a methodology that enables to apply changed data conditions which in the future can be used as a decision making and financial preparing tool for construction projects. The suggested methodology by using system dynamics can be used not only for predicting the domestic unit cost but also for other countries by changing the rates given in previous chapters. Moreover, it is expected that this methodology contributes to analyzing supply, demand chain and unit cost of other resources but reinforced bars by changing the data applied in the model. Accordingly, it is expected that the methodology suggested in this study contributes to the domestic steel industry as follows. A study of a status of the international steel industry has been performed and applied in the simulation model that contributes to future studies by suggesting the appropriate model and data input methodology. Moreover, the system dynamics simulation model shows quantitative approach and analysis to numerous factors as the main and major factors suggested in the previous chapters that it is able to see the changing values over time by adding new data sets in the future. Based on the statement above, the system dynamics simulation technique is capable of applying to various situations and fields where quantified prediction results are continuously demanding.

In spite of significance and contributions of this study mentioned above, practical limitation of this study can be described. The data has been collected from national statistical associations and steel associations. However, it revealed difficulties in founding recent data that the data used in this study is an old statistical data from the year 2005. Therefore, there is need to apply the newest data as possible to deduct more reliable results for the nearest future.

\section{ACKNOWLEDGEMENT}

This research was supported by INHA UNIVERSITY Research Grant and the National Research Foundation of Korea(NRF) grant funded by the Korea government (MEST) (NRF-2012R1A2A2A01046193).

\section{REFERENCES}

[1] M. Kim, "The Research on Liquidity and Issues of Steel Market in the Construction Industry", Master Dissertation, Seoul National University of Science \& Technology, Seoul, South Korea, 2010.

[2] J. Kang, H. Park, "Development of a Construction Performance Causal Map Using System Dynamics", Korea Institute of Building Construction (Industry), KIC, vol. 9, no. 2, pp. 63-68, 2009.
[3] Y. Park, H. Park, "Development of Tunnel Construction Cost Model Using System Dynamics", Journal of the Digital Contents Society, DCS, vol. 12, no.4, pp. 468-475, 2012.

[4] D. Vlachos, P. Georgiadis, E. Iakovou, "A system dynamics model for dynamic capacity planning of remanufacturing in closed-loop supply chains", Computers \& Operations Research, vol. 34, no. 2, pp. 367-394, 2007

[5] S. Hwang, M. Park, H. Lee, H. Kim, "A Dynamic Approach for Evaluating the Validity of Mortgage Lending Policies in Korean Housing Market", Korean Journal of Construction Engineering and Management, KICEM, vol. 11, no. 5, pp. 32-40, 2010

[6] S. Kim, M. Park, H. Lee, S. An, "Supply-Demand Forecasting Method of Qualified Engineers in Construction Using System Dynamics", Proceedings of the Korean Journal of Construction Engineering and Management, Seoul, South Korea, pp. 373-377, 2006.

[7] T. Kim, H. Jun, S. Park, S. Chang, "System Dynamics Approach to Demand and Supply of Information Security Manpower", Journal of the Korean Institute of Communications and Information Sciences, KICS, vol. 29, no. 2B, pp. 228-239, 2003

[8] W. Cha, J. Lee, W. Kwon, J. Lee, J. Chun, "Assessment Model of a Construction Company's Management Performance", Proceedings of the Architectural Institute of Korea, Kwangjoo, South Korea, pp. 661-664, 2008.

[9] Korea Iron and Steel Association, Iron and Steel Statics, 2009. Web accessed at: http://www.kosa.or.kr

[10] Korea Trade Commission, Korea Trade Commission: Economic Research on the Steel Industry, 2006, Web accessed at: http://www.ktc.go.kr

[11] World Steel Dynamics, Global Summary Reports, 2010, Web accessed at: http://www.worldsteeldynamics.com

[12] World Steel Association, Crude steel production, 2011, Web accessed at: http://www.worldsteel.org 